\title{
Importance of Stress Factors in Poultry
}

\author{
Bulent Elitok ${ }^{1 *}$ and Niyazi Bingüler ${ }^{2}$ \\ ${ }^{1}$ Department of Internal Medicine, Afyon Kocatepe University, Turkey \\ ${ }^{2}$ Private Veterinarian in Poultry Sector, Turkey
}

Submission: July 10, 2018; Published: July 18, 2018

*Corresponding author: Bulent Elitok, Department of Internal Medicine, Afyon Kocatepe University, Faculty of Veterinary Medicine, 03200/ Afyonkarahisar,Turkey, Email: elitok1969@hotmail.com

\begin{abstract}
Stress is the whole biological response to an internal or external stimulus that threatens the homeostasis of the creature in the form of anatomic, physiological, and behavioral changes. While short-term stress events do not produce significant consequences, long-term stress can cause a wide range of harmful effects on poultry production. Stress factors are well known and kept at a minimum is a very important issue in terms of poultry breeding, animal welfare and productivity increase. In this review, common stress factors in the poultry sector are researched.

Keywords: Stress;Factors;Chicken
\end{abstract}

\section{Introduction}

Larger farms, more feed, and earlier cut-off require more animals to grow in more dense environments in order to be able to meet increasing demand for protein from chicken and eggs, and this creates significant stress and stress on birds [1-4]. Stress factors cause to decreased appetite, growth retardation, and susceptibility to diseases, as well as increased mortality ratesin poultry.

Stress factors or stressors in defense stimulants are called organisms under the influence of internal and external factors such as hunger, fear, temperature change, noise, tight accommodation, infections [5]. Among the most common stress factors in cage-type poultry farming are considered to be the most common types of infectious diseases, including temperature, humidity, lack of light, crowded housing, ventilation, noise and fear [6-8].

The main effects of heat stress are increased mortality, decreased feed consumption and weight loss and egg production $[1,9]$. Because the thermal environment is a factor controlling the energy metabolism and the change. While low temperature or cold stress increases animal health, prosperity and production efficiency, high environmental temperature is one of the factors that affect egg poultry negatively [10]. During temperature stress, in addition to increased breathing alkalosis and water consumption, the amount of protein in the carcass decreases and fat deposits increase. These changes, as well as heat stress; decrease in the production of thyroid hormones and increase in the amount of corticosterone may occur in other stress conditions as well. The increased amount of corticosterone also provides the basis for infections by suppressing the immune system [11].

Light is one of the environmental factors affecting the activity and performance of poultry animals. In addition to the low yields, the increase in cannibalistic pathological movements is taking place and animal strase enters [12]. Indeed, the identification of the breeding environment is directly related to poultry physiology, reproductive and behavioral activities [13].

It has been reported that poultry grown in low intensity light environment has reduced carcass weight, malfunctions related to skeletal system, vision and reproduction, changes in animal behavior, and fear of animal stress [14]. They reported that the proportion of carcass protein decreased and the fat ratio increased in animals raised under dim light [15]. However, excessive intensity of light has also been shown to cause stress, leading to an increase in aggressive behavior $[16,17]$. Therefore, the importance of natural light in terms of animal welfare has been emphasized, emphasizing the importance of having a free circulation area for the animals to see daylight in poultry in order to increase the yield and prevent the stress [18].

Overcrowding is one of the most important and most frequent stress factors in terms of production and yield in poultry farming. Studies on overcrowded stress reported that performance parameters decreased, decreased feed consumption and weight loss, resulting in reduced productivity [19]. Crowding stress leads to changes in behavior as well as common leg problems and susceptibility to diseases [20]. As a result of crowded stress, the immunity system is suppressed with the loss of yield, and 


\section{Juniper Online Journal of Case Studies}

it sets the ground for the activation of opportunistic pathogens such as salmonella and disease formation [21].

The ventilation system is one of the important factors considered as the optimal conditions for livestock. Problems such as inadequate design of the ventilation system (insufficient number of exhaust fans and a smaller cooling area than the proposals) or incorrect placement of the sensors can cause problems in the supplies. The use and support of mathematical tools and computational techniques is crucial to ensure that the system works effectively [22].

Noise also has a significant psychological effect on the birds, and is also a potential source of fear in animals. Noise has been observed in worms exposed to stress, animals are piled up on a corner, or strangulated on a flat surface [23].

Fear describes an alarm situation in danger, a disturbance from danger, a harmonizing and at the same time harmonious energy, a psychophysiological response of the brain and neural system (Boissy, 1995). The ability to perceive a fearful violent animal is influenced by the experience, the hormonal state, and the magnitude of the causative agent [24]. The stress caused by fear in the wings stimulates the central nervous system, resulting in catecholamine secretion from the adrenal medulla, resulting in the conversion of glycogen, the energy source, to the stress factor. The corticosterone hormone also activates the accumulation of protein and fat in the body and these substances are used for vital events such as growth, egg production and regulation of the respiratory, circulatory and body temperature functions of the immune system. The release of the corticosterone hormone in stressed animals continues until the stress factor begins to rise from the middle to the corticosterone in the adrenal cortex. The depletion of adrenal cortexste corticosterone hormone leads to exhaustion and death in the poultry [25].

Not being able to get adequate feed, poor maintenance conditions, various stress factors break the resistance of animals to both infectious diseases, and when they are extremely severe, they manifest themselves as severe diseases such as epidemic diseases. At the beginning of diseases that are common in chicken breeding for today. Diseases such as C.R.D., Leukosis, Marek's disease, Tuberculosis, Pullorum, Typhus gallinarum, Flower and diphtheria, Chicken colander, Infectious Laryngotraheitis, Winged encephalomyelitis and Gumboro [5].

Inadequate and/or unbalanced nutritional status lead to metabolic stress in animals [26,27]. The lack of adequate protein, amino acids and carbohydrates in the feed or lack of balanced distribution leads to many metabolic disorders $[20,28]$. In addition, the deficiencies of the minerals in the vicinity are accompanied by many problems [29]. As a matter of fact, minerals such as sodium, potassium and chloride play a very important role in the preservation of osmotic pressure in body fluids as well as acid-base balance in the body [30].
Stress factors are well known and kept at a minimum, which is a very important issue in terms of poultry breeding, animal welfare and productivity increase. We believe this compilation will be an important resource for veterinarians working in this area[31-34].

\section{References}

1. Almeida JG, Vieira SL, Gallo BB, Conde ORA, Olmos AR (2006) Period of incubation and posthatching holding time influence on broilerperformance. Brazilian Journal of Poultry Science 8(3): 153158.

2. Rozenboim I, Tako E, Gal-Garber O, Proudman JA, Uni Z (2007) The effect of heat stress on ovarian function of laying hens. Poult Sci 86(8): $1760-1765$

3. Dixon LM (2008) Feather Pecking Behaviour and Associated Welfare Issues in Laying Hens. Avian Biology Research 1(2): 73-87.

4. Fit NF, Chirla G, Nadas S, Rapuntean L, Ognean S, et al. (2012) Haematological biochemical and microbiological studies at pigeons treated with a product based on metronidazole, oxytetracycline, furazolidone and bismuth subnitrate. Bulletin Uasvm, Veterinary Medicine 69 (1-2): 120-127.

5. Akçapınar H, Özbeyaz C (1999) Hayvan Yetiştiriciliği Genel Bilgileri. Kariyer Matbaacılık, Ankara.

6. Quinteiro-Filho WM, Rodrigues MV, Ribeiro A, Ferraz-de-Paula V, Pinheiro ML (2012) Acute heat stress impairs performance parameters and induces mild intestinal enteritis in broiler chickens: role of acute hypothalamic-pituitary-adrenal axis activation. J Anim Sci 90(6): 1986-1994.

7. Zulkifli I, Che Norma MT, Chong CH, Loh TC (2000) Heterophil to lymphocyte ratio and tonic immobility reactions to preslaughter handling in broiler chickens treated with ascorbic acid. Poult Sci 79(3): 402- 406 .

8. Wei FX, Hu XF, Xu B, Zhang MH, Li SY, et al. (2015) Ammonia concentration and relative humidity in poultry houses affect the immune response of broilers. Genet Mol Res 14(2): 3160-3169.

9. Dale NM, Fuller HL (1980) Effect of diet composition on feed intake and growth of chicks under heat stress. II. Constant vs. cyclic temperatures. Poult Sci 59(7): 1434-1441.

10. Konca Y, Yazgan O (2002) Yumurta Tavuklarında Sicaklık Stresi ve Vitamin C. Hayvansal Üretim 43(2): 16-25.

11. Öksüz K, Yalçın S (2008) İki farklı yaștaki yumurtacı tavuklarda akut ve kronik sıcak stresinin verim özellikleri, bağışıklıkla ilgili bazı organ ağırlıkları ve kan parametreleri üzerine etkileri. Yüksek Lisans Tezi. Ege Üniversitesi, İzmir.

12. Olanrewaju HA, Miller WW, Maslin WR, Collier SD, Purswell JL, et al. (2016). Effects of light sources and intensity on broilers grown to heavy weights. Part 1: Growth performance, carcass characteristics, and welfare indices. Poult Sci 95(4): 727-735.

13. Mousa Balabel TM, Mohamed RA, Saleh MM (2017) Using different light colors as a stress factor on broiler performance in Egypt. Aust J Basic \& Appl Sci 11(9): 165-170.

14. Hughes BO, Black AJ (1974) The effect of environmental factors on activity, selected behavior patterns and "fear" of fowls in cages and pens. Br Poult Sci 15: 375-380.

15. Charles RG, Robinson FE, Hardin RT, Yu MW, Feddes J, et al. (1992) Growth, body composition, and plasma androgen concentration of male broiler chickens subjected to different regimens of photoperiod and light intensity. Poult Sci 71(10): 1595-1605. 
16. Newberry RC, Hunt JR, Gardiner EE (1986) Light intensity effects on performance, activity, leg disorders, and sudden death syndrome of roaster chickens. Poult Sci 65(12): 2232-2238.

17. Deep A, Schwean-Lardner K, Crowe TG, Fancher BI, Classen HL (2010) Effect of light intensity on broiler production, processing characteristics, and welfare. Poult Sci 89(11): 2326-2333.

18. Zhao ZG, Li JH1, Li X1, Bao J (2014) Effects of Housing Systems on Behaviour, Performance and Welfare of Fast-growing Broilers. AsianAustralas J Anim Sci 27(1): 140-146.

19. Guardia S, Konsak B, Combes S, Levenez F, Cauquil L, et al. (2011) Effects of stocking density on the growth performance and digestive microbiota of broiler chickens. Poult Sci 90(9): 1878-1889.

20. Estevez I (2007) Density allowances for broilers: where to set the Limits. Poult Sci 86(6):1265-1272.

21. Gomes AV, Quinteiro-Filho WM, Ribeiro A, Ferraz-de-Paula V, Pinheiro ML, et al. (2014) Overcrowding stress decreases macrophage activity and increases Salmonella Enteritidis invasion in broiler chickens. Avian Pathol 43(1): 82-90.

22. Curı TMRC, Contı D, Vercellınor A, Massarı JM, Moura DJ, et al. (2017) Positioning of sensors for control of ventilation systems in broiler houses: a case study. Scientia Agricola 74(2): 101-109.

23. Chloupek P, Voslářová E, Chloupek J, Bedáňová I, Pıštěková V, et al . (2009) Stress in broiler chickens due to acute noise exposure. Acta Vet Brno 78(1): 93-98.

24. Jones RB (1987) The assessment of fear in the domestic fowl. In: Zayan R, Duncan IJH (Eds.), Cognitive Aspects of Social Behaviour in the Domestic Fowl. Elsevier, Amsterdam, USA, pp. 40-81.

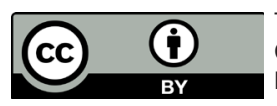

This work is licensed under Creative Commons Attribution 4.0 License DOI: 10.19080/JOJCS.2018.07.555723
25. Gray JA (1987) The Psychology of Fear and Stress. Psychology (2 $2^{\text {nd }}$ edn). Cambridge University Press, Grigor, PN (1993), UK, pp. 422.

26. Virden WS, Lilburn MS, Thaxton JP, Corzo A, Hoehler D, et al. (2007) The effect of corticosterone-induced stress on amino acid digestibility in Ross broilers. Poult Sci 86: 338-342.

27. Diarra SS, Tabuacirı P (2014) Feeding Management of Poultry in High Environmental Temperatures. International Journal of Poultry Science 13(11): 657-661.

28. Daghır NJ (2009) Nutritional strategies to reduce heat stress in broilers and broiler breeders. Lohmann information 44(1): 6-15.

29. Yarsan E, Gülec M (2003) Kanatlılarda stres, vitamin ve mineral uygulamaları. Türk Veteriner Hekimleri Birliği Dergisi pp. 55-63.

30. Balos MZ, Jaksıc S, Knezevıc S, Kapetanov M (2016) Electrolytes sodium, potassium and chlorides in poultry nutrition. Arhiv veterinarske medicine 9(1): 31-42.

31. Rozenboim I, Biran I, Uni Z, Robinzon B, Halevy O (1999) The effect of monochromatic light on broiler growth and development. Poult Sci 78(1): 135-138.

32. Huff GR, Huff WE, Balog JM, Rath NC, Anthony NB, et al. (2005) Stress response differences and disease susceptibility reflected by heterophil to lymphocyte ratio in Turkeys selected for increased body weight. Poult Sci 84(5): 709-717.

33. Boissy A (1995) Fear and fearfulness in animals. Q Rev Biol 70(2): 165191.

34. Aydın N (1984) Bölge Tavukçulugunu Etkileyen Hastalık Sorunları ve Alınması Gerekli Hijyenik Önlemler. Selçuk Üniversitesi Vet Fak Dergisi Özel Sayı, pp. 77-90.

\section{Your next submission with Juniper Publishers will reach you the below assets}

- Quality Editorial service

- Swift Peer Review

- Reprints availability

- E-prints Service

- Manuscript Podcast for convenient understanding

- Global attainment for your research

- Manuscript accessibility in different formats

(Pdf, E-pub, Full Text, Audio)

- Unceasing customer service

Track the below URL for one-step submission https://juniperpublishers.com/online-submission.php 